PEREIRA, AM; QUEIROGA, RCF; PEREIRA, FHF; SILVA, ZL; SANTOS, EF. 2017. Characteristics of muskmelon fruits in relation to temporary row cover and the number of fruits. Horticultura Brasileira 35: 591-598. DOI - http://dx.doi.org/10.1590/S0102-053620170418

\title{
Characteristics of muskmelon fruits in relation to temporary row cover and the number of fruits
}

\author{
Auderlan M Pereira ${ }^{1}$; Roberto CF Queiroga ${ }^{2}$; Francisco Hevilásio F Pereira ${ }^{2}$; Zaqueu L Silva ${ }^{2}$; Everaldo \\ F Santos ${ }^{2}$
}

${ }^{1}$ Universidade Federal de Viçosa (UFV), Viçosa-MG, Brasil; pereiraam@outlook.com; ${ }^{2}$ Universidade Federal de Campina Grande (UFCG), Pombal-PB, Brasil; robertoqueiroga@ccta.ufcg.edu.br (autor para correspondência); fhfpereira@hotmail.com; everaldocajazeirinhas@ hotmail.com; zaqueulopes@yahoo.com.br

\begin{abstract}
The muskmelon plants allow several ways to manipulate sources/ drains ratio. The objective of this work was to evaluate characteristics of the productivity and quality of Cantaloupe melon fruits due to the temporary use of row cover and the number of fruits per plant. The experiment was carried out from August to December 2014, at Universidade Federal de Campina Grande (UFCG), Paraiba State, Brazil. The experimental design was randomized blocks with treatments allocated in split plots $5 \times 3$, with four replicates. The authors reported permanence time of the row cover at different times in the plot [20, 24, 28, 32, and 36 days after transplanting (DAT)] and, in the subplots, the number of fruits per plant (plants with one fruit, plants with two fruits and fruit-free setting plants). The authors evaluated traits of production and quality of fruits. The permanence time of row cover and number of fruits per plant promoted changes in the productivity and quality of the muskmelon fruits. The permanence of the row cover from 20 to 36 DAT provided reduction in the total soluble solids. The average fruit mass and fruit yield reached the maximum value with the permanence of the row cover up to 26.6 and 25.1 DAT, respectively. Plants with one and two fruits presented higher average fruit mass, but with lower productivity compared to the plant with fruit-free setting.
\end{abstract}

Keywords: Cucumis melo, competition, physiology and yield.

\section{RESUMO}

Características de frutos de melão em função da cobertura temporária com agrotêxtil e do número de frutos

As plantas do meloeiro permitem várias formas de manipulação da relação entre a fonte e o dreno. Esse trabalho teve por objetivo avaliar as características de produção e qualidade de frutos de melão Cantaloupe em função da utilização temporária do agrotêxtil e do número de frutos por planta. $\mathrm{O}$ experimento foi realizado no período de agosto a dezembro de 2014, na Universidade Federal de Campina Grande (UFCG). O delineamento experimental utilizado foi de blocos casualizados com os tratamentos alocados em um arranjo em parcelas subdivididas $5 \times 3$, com quatro repetições. Na parcela constaram as diferentes épocas de permanência do agrotêxtil [20, 24, 28, 32, e 36 dias após o transplante (DAT)], e nas sub parcelas o número de frutos por planta (plantas com um fruto, plantas com dois frutos e com fixação livre de frutos). Foram avaliadas características de produção e de qualidade dos frutos. As épocas de permanência do agrotêxtil e o número de frutos por planta promoveram alterações na produtividade e qualidade dos frutos do meloeiro. A permanência do agrotêxtil de 20 para 36 DAT proporcionou redução nos sólidos solúveis totais. A massa média do fruto e a produtividade de frutos atingiram o máximo valor com a permanência do agrotêxtil até 26,6 e 25,1 DAT, respectivamente. Plantas com um e dois frutos apresentaram maior massa média do fruto, porém com menor produtividade comparada à planta com fixação livre de frutos.

Palavras-chave: Cucumis melo, competição, fisiologia e rendimento.

\section{Received on December 10, 2015; accepted on January 13, 2017}

$\mathrm{M}$ elon fruits are greatly appreciated and very popular all over the world. It is one of the fresh fruits which are the most exported to all regions of Brazil (AGRIANUAL, 2014). In 2013, $575,386 \mathrm{t}$ of melons were produced in Brazil, in 22,810 ha, highlighting the Northeast region with $95.0 \%$ of the total production of the country, highlighting the State of Rio Grande do Norte and Ceará. In the State of Paraíba, the cultivation of this vegetable crop is represented in small areas with an average productivity of only $18.8 \mathrm{t} / \mathrm{ha}$ (IBGE, 2015).

The necessary condition for success in growing this plant is directly related to high luminosity, temperature, low rainfall and low relative humidity (Medeiros et al., 2007). These weather conditions are found in Sertão Region of the State of Paraíba, however, due to low level of technology and inappropriate plant management adopted by small producers, the production has been low. Thus, the importation of melons from other States has been common aiming to meet the internal demand.

Melon plants allow several ways to manipulate sources/drains ratio which may influence plant and fruit development and close to harvest, an increase of fruit brix (ValantinMorison et al., 2006). Thus, one of the alternatives to change the distribution of dry matter of the plant and allow greater supply of photo-assimilates for the growth and subsequent sweetening of fruits would be by removing the row 
cover (Non Woven Fabric - TNT) on different times and fruit setting in plant aiming to promote fructification control.

In addition to pest control, the use of the row cover can alter provisionally sources/drains ratio of the melon plant, by delaying the pollination of this species (Santos et al., 2015). In this sense, knowing the best time to remove this mulch is of fundamental importance, since this management is able to promote changes in fructification, as the row cover does not allow bees to enter, so the flowers are not available to be pollinated (Santos et al., 2014).

In two experiments on the municipality of Baraúnas, Rio Grande do Norte, Brazil, Cantaloupe melon 'Torreon', cultivated with and without the use of row covers, a productivity of 29.28 and $25.74 \mathrm{t} / \mathrm{ha}$ was obtained when the row cover was used up to 28 days after transplanting and without the row cover; moreover, the use of row covers promoted an increase of fruit productivity intended for the external market (Medeiros et al., 2007). Additionally, in a study carried out with melon plants, the treatments with temporary protection with row covers did not affect the total productivity; however, pulp firmness showed a linear increasing, whereas the titratable total acidity, the total soluble sugars, soluble solids and $\mathrm{pH}$ showed a decrease with an increase of permanence time of the row cover on the plants (Santos et al., 2015). In another study carried out with melon crop, a 14-day delay in fructification promoted higher number of fruits per plant, without significant increase of soluble solid contents, though (Long et al., 2004).

On the other hand, in annual crops just like fruit vegetables, a higher number of fruit setting per plant can change the biomass distribution in its different organs since these fruits are strong metabolic drains and take priority over vegetative drains which is noticeably reduced during fructification phase (Aumonde et al., 2011).

The increase in number of fruits reduced the average dry matter of the fruits, without affecting the production and distribution of total dry matter of the plant; however, production and distribution of the fresh matter for the fruits show a different behavior when compared to the behavior of the dry matter, being both benefited with this increasing (Duarte \& Peil, 2010). The increase of fruit set induces competition for assimilates between drains and leads to a decrease of the weight of individual fruits and soluble solid content of the pulp in Cantaloupe melon (ValantinMorinson et al., 2006). For watermelon plant, when the same were tutored with two fruits, a reduction in fruit matter and soluble solids and an increase in the crop productivity was observed (Lins et al., 2013).

This study was developed to evaluate the productivity and quality of the melon fruits due to the row cover removal at different times and number of fruits per plant under the conditions of Sertão Region of the State of Paraiba.

\section{MATERIAL AND METHODS}

The experiment was carried out from August to December 2014, in Centro de Ciências e Tecnologia Agroalimentar at Universidade Federal de Campina Grande, located in the municipality of Pombal, Paraiba State,

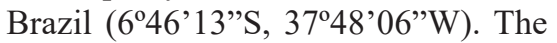
soil was classified as Fluvic Neossol (Embrapa, 2008) and presented the following characteristics: $\mathrm{pH}$ (water $1: 2.5)=7.0 ; \mathrm{Ca}=5.9 \mathrm{cmolc} / \mathrm{dm}^{3} ; \mathrm{Mg}=$ $2.6 \mathrm{cmolc} / \mathrm{dm}^{3} ; \mathrm{K}=0.4 \mathrm{cmolc} / \mathrm{dm}^{3}$; $\mathrm{Na}=0.02 \mathrm{cmolc} / \mathrm{dm}^{3} ; \mathrm{Al}=0.0 \mathrm{cmolc} /$ $\mathrm{dm}^{3}$ and $\mathrm{P}=8.4 \mathrm{mg} / \mathrm{dm}^{3}$. The climate of the region according to Thornthwaite is semi-arid and according to Köppen is BSwh', dry and very hot, with two climatic seasons, dry (June to January) and rainy (February to May).

The experimental design was randomized blocks. The treatments were allocated in split plots $5 \times 3$, with four replicates. In the plot, the treatments consisted of different seasons at different times to remove the row cover (TNT) $(20,24,28,32$ and 36 days after the transplanting), used as low tunnel and, in the subplots the treatments consisted of number of fruits per plant (one fruit, two fruits and fruit-free setting plants).

Sowing was carried out on August
22, 2014, in polystyrene trays with 162 cells filled with commercial agricultural substrate for leafy vegetable seedling production.

Soil preparation consisted of plowing, harrowing and, then, the authors opened furrows for planting and top dressing fertilization. Planting and top dressing fertilization managements were carried out according to the soil chemical analyses. Planting fertilization with $\mathrm{P}_{2} \mathrm{O}_{5}$ (simple superphosphate) was performed with $80 \mathrm{~kg} / \mathrm{ha}, 100 \%$ in foundation adding $10 \%$ of $\mathrm{N}$ and $\mathrm{K}_{2} \mathrm{O}$. For the top-dressing fertilization, the authors used $\mathrm{N}$ (urea) and $\mathrm{K}_{2} \mathrm{O}$ (potassium chloride) in the amount of 120 and $150 \mathrm{~kg} / \mathrm{ha}$ via daily fertigation during seven days beginning three days after transplanting. In each fertigation, the authors applied, respectively, the following nutrient: $1^{\mathrm{st}}=5.0 \%$ of $\mathrm{N}$ and $10.0 \%$ of $\mathrm{K}_{2} \mathrm{O} ; 2^{\text {nd }}=10.0 \%$ of $\mathrm{N}$ and $10.0 \%$ of $\mathrm{K}_{2} \mathrm{O} ; 3^{\text {rd }}=15.0 \%$ of $\mathrm{N}$ and $15.0 \%$ of $\mathrm{K}_{2} \mathrm{O} ; 4^{\text {th }}, 5^{\text {th }}$ and $6^{\text {th }}=20.0 \%$ of $\mathrm{N}$ and $18.0 \%$ of $\mathrm{K}_{2} \mathrm{O} ; 7^{\text {th }}=10.0 \%$ of $\mathrm{N}$ and $11.0 \%$ of $\mathrm{K}_{2} \mathrm{O}$.

Fifteen days after sowing, on December 6, 2014, when the seedlings showed the second definitive leaf, the authors carried out the transplanting. The hybrid Hopey King of Cantaloupe melon was planted at the spacing of $2.0 \mathrm{x} 0.8 \mathrm{~m}$, one plant per pit. The plot consisted of one row with 15 plants, being the useful area of the subplots of three plants. Irrigation was carried out using $2 \mathrm{~L} / \mathrm{h}$-flow drippers tutored with the aid of tensiometers and splitted twice a day.

The plants were tutored according to the recommended treatments, and the row cover was removed at different times and the control of the fructification per plant through fruit thinning daily. During the crop cycle, manual hoeing was carried out when removing the TNT and, pest control was carried out with fungicide and insecticide recommended for the crop, when necessary. The authors observed the occurrence of pests, being the most frequent and expressive caterpillars, aphids and whitefly. In order to control the catterpilars, the authors used insecticide-acaricide chlorpyrifos, acting through contact and ingestion; and to control the aphids 
and whitefly, the authors used systemic insecticide thiamethoxam.

Harvest began on day 03 and finished on November 14, 2014. Production traits were evaluated using all the fruits from the subplot and the evaluations related to the quality of the fruit were obtained from the fruit samples of the subplot totaling twelve fruits per treatment.

After fruit harvest the authors evaluated number of fruits per plant, only for plants with fruit-free setting counting them in the useful area of the plot, average mass of the fruit ( $\mathrm{g} /$ fruit) through the ratio between number of total fruits/number of plants of useful plot and total productivity of fruits ( $\mathrm{t} / \mathrm{ha}$ ) by estimating for 1 ha in experimental level.

The quality traits evaluated were pulp firmness [with the aid of a manual penetrometer (McCormick model FT 327), 12 mm-diameter tip]; length and diameter $(\mathrm{cm})$ of the fruits (using a digital paquimeter); fruit shape index (relationship between the longitudinal length and the transversal diameter of the fruit); pulp thickness $(\mathrm{cm})$ (reading of the equatorial region of the fruit, after being cut in the longitudinal direction, using a digital paquimeter); total soluble solids (\%) and total acidity ( $\%$ of citric acid), in samples of fruit slices taken in the longitudinal direction and homogenized in a fruit centrifuge to obtain the juice; the total soluble solids were determined using a digital refractometer obtaining values in ${ }^{\circ}$ Brix, whereas for total titratable acidity, a $10-\mathrm{mL}$ aliquot of juice was used, in duplicate, in which the authors added $50 \mathrm{~mL}$ of distilled water and three drops of $1 \%$ alcoholic phenolphthalein. Then, the authors carried out the titration with solution of $\mathrm{NaOH} 0.1 \mathrm{~N}$ until the turning point.

Data were submitted to the analysis of variance using the software SAEG 9.0 at $5 \%$ of probability. Regression analysis was carried out, using software Table Curve 2D for averages observed for the evaluated traits in relation to the time of the row cover removal. In this case, the adjusted response functions were chosen based on the significance of the parameters of the regression equation, in the biological response of the variable in this study and in the coefficient of determination. On the other hand, the authors carried out the Tukey test at 5\% probability for the averages observed in the evaluated traits in relation to the number of fruits per plant.

\section{RESULTS AND DISCUSSION}

Number of fruits per plant and fruit mass are the main components for productivity formation of muskmelon. The plants tutored with one or two fruits did not alter the number of fruits per plant in relation to the treatments applied. However, in plants with fruit-free setting, the authors obtained average of 2.3, 3.7, 2.9, 2.5 and 2.3 fruits per plant after the row cover removal at 20.0, 24.0, 28.0, 32.0 and 36.0 days after transplanting (DAT), respectively.

According to the results obtained using $\mathrm{F}$ test of analysis of variance, the authors observed significant effect of isolated factors time of row cover removal $\mathrm{x}$ number of fruits per plant on the fruit mass, whereas significant effect of interaction of these factors for the total productivity of fruits was observed $(\mathrm{p}<0.05)$.

In average fruit mass, the authors observed a quadratic response with maximum values of $1.948 \mathrm{~kg} / \mathrm{plant}$ at 26.6 days after row cover removal, from this time on, the authors observed a reduction of fruit mass of $0.470 \mathrm{~kg} /$ fruit, which corresponds to $26.3 \%$ of the mass after row cover removal at 36.0 DAT (Figure 1A).

In this sense, the plants which had the row cover removed earlier resulted in a longer period of time of radiation exposure, which could have contributed to increase the photosynthetic activity of plants and, then, higher production and photo-assimilate transport for the fruit growth. From 26.6 days after row cover removal, the fruits presented lower average mass, probably due to the fact that the delay in fruit setting had provided the plant to invest photoassimilates in vegetative growth and, so that due to higher number of branches emitted had resulted in competition between the source and the drain. The authors concluded that the fruits had grown less in plants in which the row cover was removed after 26.6 DAT in relation to the ones observed in the field due to the higher occurrence of weeds inside the tunnel when the cover was removed later, since row mulching was not used, the interspecific competition increased. This fact could contribute to a higher amount of leaves in senescence stage near harvest causing a possible reduction in photosynthetic activity, production and photo-assimilate transport for the fruit growth, mainly when the row cover was removed at 36.0 DAT.

In relation to the number of fruits, in plant, as it was expected, plants tutored with one or two fruits showed higher average mass of fruit in comparison to plants with free setting (Table 1). The fruit mass is related to the ratio of number of fruits in plant/drains which compete only with the vegetative part of the plant, but in great quantity also compete, among them, for photoassimilates which lead to fruits with lower mass. According to Fagan et al. (2006), when the fruit density per plant is increased, fruit demand for assimilates rises installing a strong photo-assimilate competition among them. The authors highlight that some market niches opt for fruits with lower fresh mass aiming immediate consume and, this is a characteristic that can be exploited in function of the consumer market (Melo et al., 2014).

For total productivity, the authors found a quadratic response with maximum values of 12.9, 26.4 and 35.4 $\mathrm{t} / \mathrm{ha}$ at $26.1,25.2$ and 23.9 days after row cover removal from plants with one, two and free setting of fruits, respectively (Figures 2A, 2B and 2C). From these days on, a reduction of 20.1 and $24.6 \%$ of total productivity of fruits in plants with one, two and free setting of fruits, respectively, decreased in relation to row cover removal at $36.0 \mathrm{DAT}$; in plants with fruit-free setting and lowest productivity estimated of $22.4 \mathrm{t} / \mathrm{ha}$ at 33.4 DAT we observed a reduction of $36.7 \%$ in productivity.

Regardless of the number of fruits in the plant, the maximum productivity was reached when the row cover was removed. The row cover removal during 
the beginning of the plant growth at 20 and 24 DAT when compared to the removal carried out at 28, 32 and 36 DAT was advantageous for the crop as it allowed the plant to be exposed to a higher solar radiation, and lower weed occurrence due to hoeings being carried out at the time of the row cover removal and milder temperatures due to the row cover removal. The authors expected that due to row cover removal being carried out later, plant fructification would be increased due to the formation of higher number of branches and flowers; however, in these conditions the authors verified that the greatest branch interlace which makes the cultural practice, just as hoeings and branch combing, difficult and because of this, increased the flower falling in plant. The authors also highlight that fruits set later grew in stress conditions, since it is common, in melon plant, pest and disease occurrences from the middle to the final phase of crop cycle when the fruits did not complete their commercial growth and ripeness. In this study, the most appropriate time for row cover removal which provided highest average matter of fruits was near the time which was observed for the crop productivity.

Studying the unfolding of the periods of the row cover removal for each fruit setting, as it was already expected, the authors verified that the productivity was higher when the plant was tutored with fruit-free setting and two fruits per plant when compared to plants with only one fruit (Table 2). In melon plant, the number of fruits and the average mass of the plant, are determining traits in order to define the crop productivity,

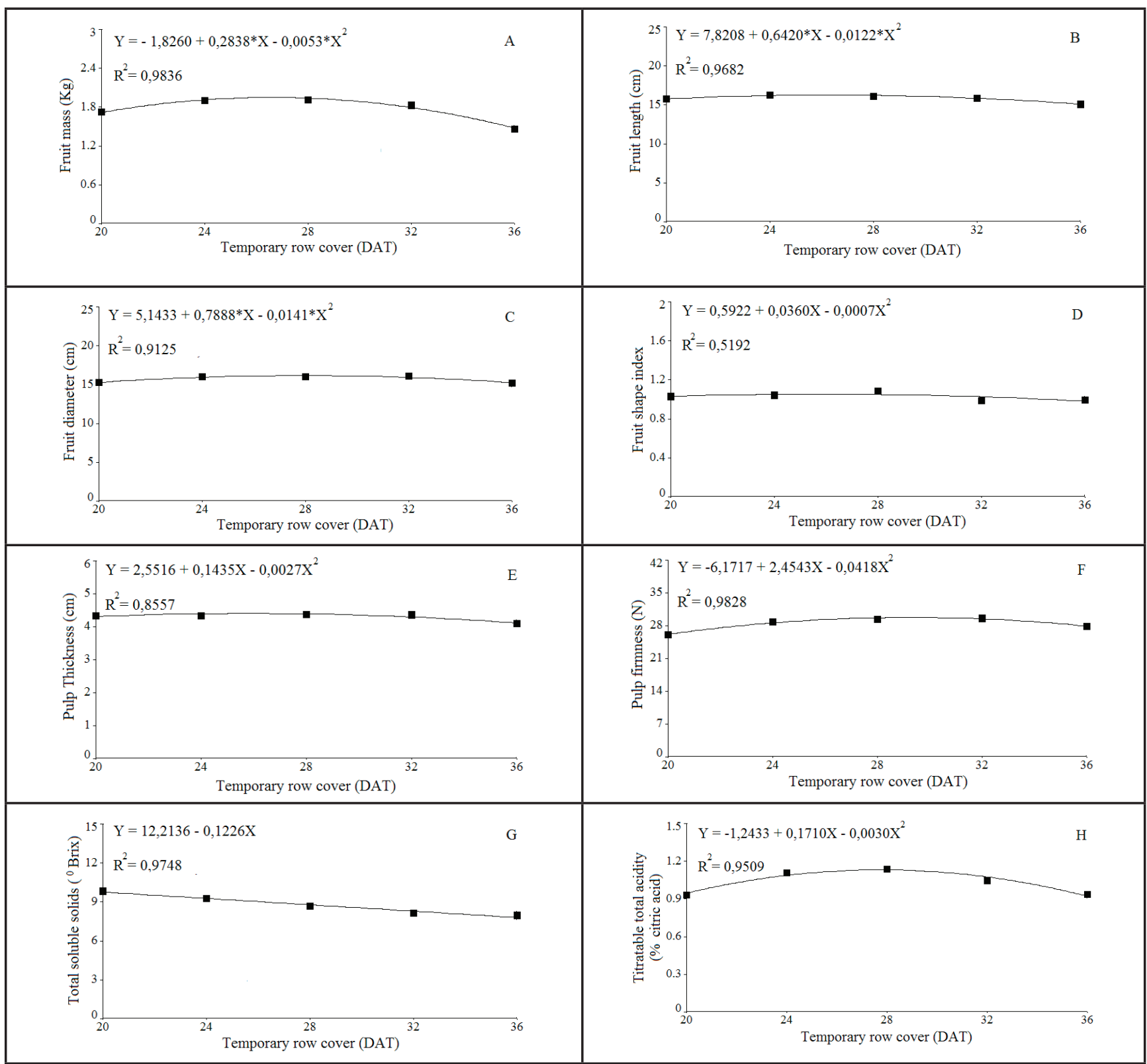

Figure 1. Estimated values of average fruit mass (A), fruit length (B), fruit diameter (C), fruit shape index (D), pulp thickness (E), pulp firmness $(\mathrm{F})$, total soluble solids $(\mathrm{G})$ and titratable total acidity $(\mathrm{H})$ in muskmelon pulp in relation to permanence of the row cover. Pombal, UFCG, 2015. 
which can suffer alterations, in relation to partitioning of assimilates in plant. In this study, plants tutored with two fruits and fruit-free setting when compared to plants with only one fruit showed the highest total productivity of fruits in relation to higher number of fruits per plant. In these plants, the fruits showed lower average mass, however, due to a higher number of fruits per plant and per area, the compensation of the loss of its average mass per area in relation to plants with only one fruit was observed, and a higher total productivity of fruits was obtained. Queiroga et al. (2009) obtained for cultivars of Cantaloupe melon results in which plants tutored with two fruits showed the highest total productivity, in relation to higher number of fruits per plant and per hectare.

The authors observed significant effect of isolated factors times of row cover removal and number of fruits per plant for length and diameter of the fruit $(p<0.05)$; for other traits, such as, fruitshape index, pulp thickness and pulp firmness, the authors did not observe any significant difference for any of studied factors nor for interaction.

For length, diameter and fruit-shape index, the authors noticed a quadratic response with maximum values of 16.2 $\mathrm{cm}, 16.0 \mathrm{~cm}$ and 1.1 at $26.3,27.9$ and 25.7 DAT regardless of the number of fruits on plants (Figures 1B, 1C and 1D). Comparing these times with row cover removal at 36.0 DAT, the authors verified a reduction of $1.2 \mathrm{~cm}(7.2 \%)$, $0.8 \mathrm{~cm}(5.0 \%)$ and $0.1(9.1 \%)$ in these variables. This implies that the greater permanence of the plants under the row cover could have caused reduction in incident radiation and high temperature due to the difficulty of ventilation inside the tunnel affecting the growth of plant

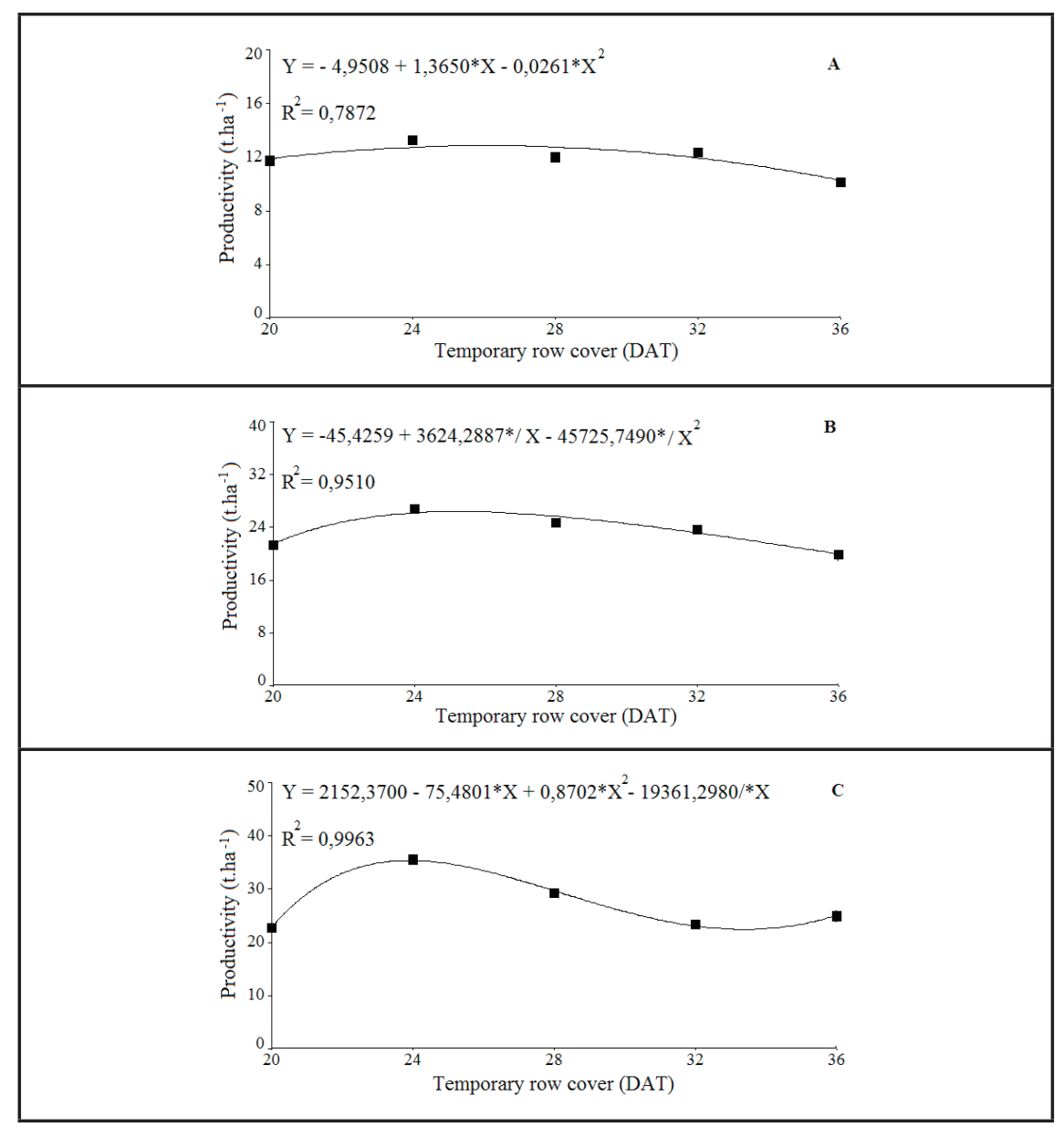

Figure 2. Estimated values of total productivity of muskmelon through interaction unfolding between row cover permanence and number of fruits per plant $(\mathrm{A}=$ plants with one fruit; $\mathrm{B}=$ pants with two fruits and $\mathrm{C}=$ fruit-free setting). Pombal, UFCG, 2015. and fruit in melon plant.

Higashi et al. (1999) concluded that the size of muskmelon fruit is defined by the number of pericarp cells, and the differences in the number of cells are caused by different genetic factors, which control the cell proliferation in melon fruit development. Moreover, these authors also state that the action of these genetic factors is affected by environmental factors, especially temperature, which can influence the number of cell divisions of each cell of the fruit, and pericarp cells, determining, the final fruit size.

Another fact is that although the delay in the row cover removal had provided plants with greater leaf area due to the absence of drains (fruits), fruit development remained constant concerning length and diameter without changing significantly the fruit shape, showing that the values observed are close to 1.0, which gives the fruit spherical shapes. In muskmelon, the shape index is an important trait of quality in the classification and standardization, allowing to determine the acceptance and appreciation of the product for certain markets; it also defines packaging and the arrangement of the fruits inside, since the fruits with shape index close to 1.0 are preferable to the market, higher than this value (elongated) and lower than this value (flattened) compromise the fruit accommodation in packaging (Purquerio \& Cecílio Filho, 2005).

On the other hand, when studying the number of fruits per plant, the authors found that plants with one or two fruits showed longer length and greater diameter of fruits when compared to plants with fruit-free setting for fruitshape index. The authors did not find significant variation, probably due to small variations found in length and diameter of the fruits (Table 1). According to Valantin-Morinson et al. (2006), fruit loading in plants influenced the growth rate and the final size of the fruit, since, in muskmelon fruits, all cellular expansion occurs after anthesis and cell division continues at a low rate, being the cell number, at the end of anthesis, the key factor which contributes to the variation of the final 
Table 1. Average values for fruit average mass (MF), fruit length (CF), fruit diameter (DF), fruit shape index (IFF), pulp thickness (EP), pulp firmness (FP), soluble solids (SS) and total acidity (AT) of muskmelon pulp in relation to number of fruits per plant. Pombal, UFCG, 2015.

\begin{tabular}{lcccccccc}
\hline $\begin{array}{l}\text { Number of fruits } \\
\text { per plant }\end{array}$ & $\begin{array}{c}\text { MMF } \\
(\mathbf{g} / \text { fruit) }\end{array}$ & $\begin{array}{c}\text { COMP } \\
(\mathbf{c m})\end{array}$ & $\begin{array}{c}\text { DIAM } \\
(\mathbf{c m})\end{array}$ & $\mathbf{I F F}$ & $\begin{array}{c}\text { EP } \\
(\mathbf{c m})\end{array}$ & $\begin{array}{c}\text { FP } \\
(\mathbf{N})\end{array}$ & $\begin{array}{c}\text { SST } \\
\left({ }^{\mathbf{0}} \text { Brix }\right)\end{array}$ & $\begin{array}{c}\text { ATT } \\
(\% \text { citric acid) }\end{array}$ \\
\hline Plants with 1 fruit & $1.91 * \mathrm{a}$ & $16.10 \mathrm{a}$ & $16.04 \mathrm{a}$ & $1.00 \mathrm{a}$ & $4.41 \mathrm{a}$ & $29.49 \mathrm{a}$ & $9.29 \mathrm{a}$ & $0.13 \mathrm{a}$ \\
Plants with 2 fruits & $1.86 \mathrm{a}$ & $16.08 \mathrm{a}$ & $15.81 \mathrm{a}$ & $1.01 \mathrm{a}$ & $4.38 \mathrm{a}$ & $28.14 \mathrm{a}$ & $8.81 \mathrm{a}$ & $0.13 \mathrm{a}$ \\
Fruit-free setting & $1.53 \mathrm{~b}$ & $15.45 \mathrm{~b}$ & $15.29 \mathrm{~b}$ & $1.01 \mathrm{a}$ & $4.24 \mathrm{a}$ & $27.77 \mathrm{a}$ & $8.86 \mathrm{a}$ & $0.11 \mathrm{a}$ \\
\hline CV (\%) & 10.26 & 4.68 & 4.08 & 3.58 & 5.33 & 11.20 & 26.50 & 21.58 \\
\hline
\end{tabular}

*Averages followed by same letters in the columns do not differ significantly, from each other, by Tukey test, at $5 \%$ probability.

fruit size, mainly, due to the influence on ability of the fruits to attract assimilates after pollination. It is important to consider that the variations of final fruit size can be interpreted as consequence of the two processes: the strength of the drain during the period of cell division and fruit growth during cell expansion.

Charlo et al. (2009), studying net melon with two and three fruits per plant, verified that plants tutored with two fruits showed higher averages for longitudinal and transversal diameter of the fruit highlighting that lower competition due to a reduced number of drains provided higher fruit growth. These same authors also state that fruit setting did not influence significantly the fruit shape index.

In relation to thickness and firmness of pulp, the authors obtained quadratic responses with maximum estimated values of $4.4 \mathrm{~cm}$ and $29.8 \mathrm{~N}$ reached at 25.8 and 29.3 DAT, respectively, regardless of the number of fruits in the plant (Figures $1 \mathrm{E}$ and $1 \mathrm{~F}$ ). From this time of row cover removal, the authors verified a reduction of $0.3 \mathrm{~cm}$ $(6.8 \%)$ for pulp thickness in relation to the row cover removal at 36.0 DAT and, an increase of $3.6 \mathrm{~N}(12.1 \%)$ in relation to the time of the row cover removal at 20.0 DAT. Pulp thickness accompanies fruit growth in terms of length and diameter showing a similar response, since the authors noticed a reduction in length and diameter of the fruits when the row cover was removed at 26.3 and 27.9 DAT.

The highest number of fruit setting did not provide a significant variation for pulp thickness (Table 1). Due to the increase of length and diameter of fruits do not reflect in a significant increase in pulp thickness, this may lead to an increase in the internal cavity of the fruit. Different results were observed by Queiroga et al. (2009), concluding that the pulp thickness was higher in fruits of plants with lower number of fruits and state that the higher pulp thickness is desirable, since it increases the weight and the edible part, improving the quality of the fruit. Silva et al. (2014) reported that the ideal fruit should have thick pulp and small internal cavity, attributes which give the fruit better resistance to transport and longer shelf life.

In relation to pulp firmness, the authors noticed a reduction in value from 29.3 DAT after the row cover removal. This probably occurred due to the lower fruit growth in these periods according to what was shown in length, diameter and fruit matter. The lowest pulp firmness observed in fruits of plants from which the row cover was removed earlier could be justified due to the longest period in which the fruits had to grow and complete the final stage of ripening until harvest. The ripening of fruits occurs through several reactions, both of synthesis and of degradation, culminating in the loss of pulp firmness, parameter which is considered as one of quality attributes (Fontes et al., 2008). Although the pulp firmness was not significantly influenced by the applied treatments (Table 1), the authors noticed that these results are higher than expected for Cantaloupe melon which is around 23.6 N (Nogueira et al., 2001).

The total soluble solids and total acidity were not influenced significantly by factors time of row cover removal and number of fruits per plant, as well as, interaction ( $\mathrm{p} \geq 0.05)$.
Soluble solids, expressed as percentage of fresh matter, present high positive correlation with sugar contents and, thus, it is generally accepted as an important trait of quality (Melo et al., 2012). For soluble solids, a decreasing linear response was found, with a delay in the row cover removal from 20.0 to 36.0 DAT with a decrease of its value from 9.8 to $7.8 \%$ (Figure $1 \mathrm{G}$ ).

This reduction of $20.4 \%$ in soluble solids of the fruits with the delay in the row cover removal was not expected, mainly because the leaf area of the plant presented an inverse behavior (data not shown) with the delay in row cover removal, and being the removal very important in production and transport of photo-assimilates both for fruit growth and for final phase of ripening. This trend of reduction observed in this variable is probably due to the delay in the row cover removal at 20.0 DAT compared to 36.0 DAT. This allows the plant to receive higher quantity of radiation increasing the photosynthetic activity, with production and transport of photo-assimilates for growth and sweetening of fruits. Another factor observed is that as the row cover removal was delayed, the plants suffered more with the competition with the weeds for the available resources. Additionally, the plants at the end of the cycle showed signs of senescence on leaves due to higher occurrences of pests and diseases, which contribute to reduce photo-assimilates supply for the final phase of fruit sweetening.

The authors obtained average value of soluble solids above the minimum required by importers, 9.0\% (Kader, 2002), only for fruits when the row cover removal was carried out at 20.0 
and 24 DAT with values of 9.8 and $9.3 \%$, respectively. Thus, for demanding markets of sweeter fruits, this can be a primary factor in the differentiation of the product by the consumer, mainly by this preference for larger and sweeter fruits.

Although the number of fruits per plant did not influence the soluble solids in fruit pulp, the authors observed a tendency to present higher value in fruits of plants tutored with only one fruit (Table 1) in relation to a greater leaf area per fruit allowing higher supply of photo-assimilates at the final phase of sweetening fruits. In this sense, soluble solids are directly related to sugar contents and competition for assimilates between fruits in plant reduced soluble solid contents in melon fruit pulp (Valantin-Morison et al., 2006; Queiroga et al., 2009).

For total acidity observed in melon fruit pulp, the authors obtained a quadratic response with maximum value of $1.1 \%$ of citric acid reached at 27.8 DAT of row cover removal (Figure 1H). From this time of row cover removal, the authors reported a decrease of $0.2 \%$ of citric acid (16.4\%) for total acidity up to 36.0 DAT. In fruits, in general, acidity represents one of the main components of flavor, since the fruit acceptance depends on the balance between acids and sugars (Kader, 2002).

For soluble solids, the total acidity was also not significantly influenced by the number of fruits in the plant (Table 1 ), although the number of fruits per plant is one of the factors related to cultural management with potential effect on the quality of melon fruits, since the change in the ratio of leaf area per fruit has the ability to modify the ratio between source and drain, and partitioning assimilates in plant (Costa et al., 2004). These same authors verified a reduction in total acidity of hybrid Bônus $\mathrm{N}^{\circ} 2$ on plants with two fruits, compared to plants with fruit-free setting. However, Queiroga et al. (2009) found similar result to the one found in this study as they did not verify change of total acidity through the variation of number of fruits per plant.

The studied factors promoted alterations in productivity and quality of melon fruits, especially in the fruit matter and in the productivity of fruits that reached the maximum value with the permanence of the row cover until 26.6 and 25.1 DAT, regardless of the number of fruits in the plant, and that the permanence time of row cover on the plants provided lower values for total soluble solids. Additionally, concerning fruit growth, values were obtained in plants with one or two fruits compared to plants with free setting, however with lower total fruit productivity. Finally, in all treatments, the use of row cover from 24 DAT made cultural practices, such as hoeing and plant combing difficult, due to the branch interlace inside the tunnel.

\section{ACKNOWLEDGEMENT}

To Centro de Ciências e Tecnologia Agroalimentar at Universidade Federal de Campina Grande for the availability of the experimental area, laboratories and technicians.

\section{REFERENCES}

AGRIANUAL. 2014. Anuário da Agricultura Brasileira. São Paulo: Agra FNP Consultoria e Comércio, 334 p.

AUMONDE, TZ; PEDÓ, T; LOPES, NF; MARAES, DM; PEIL, RMN. 2011. Partição de matéria seca em plantas do híbrido de mini melancia Smile enxertada e não enxertada. Revista Brasileira de Biociências 9: 387-391.

CHARLO, HCO; CASTOLDI, R; VARGOS, PF; BRAZ, LT. 2009. Desempenho de híbridos de melão-rendilhado cultivados em substrato. Revista Cientifica 37: 16-21.

COSTA, CC; CECÍLIO FILHO,AB; CAVARIANI, RL; BARBOSA, JC. 2004. Concentração de potássio na solução nutritiva e a qualidade e o número de frutos de melão por planta em hidroponia. Ciência Rural 34: 731-736.

DUARTE, TS; PEIL, RMN. 2010. Relações fonte:dreno e crescimento vegetativo do meloeiro. Horticultura Brasileira, 28: 271276.

EMBRAPA. 2008. Centro Nacional e Pesquisa em Solos. Sistema Brasileiro de Classificação de Solos. Brasilia: Embrapa-SPI; Rio de Janeiro: Embrapa-Solos, 306 p.

FAGAN, EB; MEDEIROS, SLP; SIMON, J; LUZ, GL; BORCIONI, E; JASNIEWICZ, LR; CASAROLI, D; MAFRON, PA. 2006. Evolução e partição de massa seca do meloeiro em hidroponia. Acta Siencia Agronomy, 28:
165-172.

FONTES, RV; SANTOS, MP; FALQUETO, AR; SILVA, DM. 2008. Atividade da pectinametilesterase e sua relação com a perda. Revista Brasileira Fruticultura, 30: 54-58.

HIGASHI, K.; HOSOYA, K.; EZURA, H. 1999. Histological analysis of fruit development between two melon (Cucumis melo L. reticulatus) genotypes setting a different size of fruit. Journal of Experimental Botany 50: 1593-1597.

IBGE. 2015. Instituto Brasileiro de Geografia e Estatística. Indicadores conjunturais produção agrícola/agricultura. Disponível em: <http://www.ibge.gov.br/> Acesso em: 16 de jan. de 2015.

KADER, AA. 2002. Standardisation and inspection of flesh fruit and vegetables. In 'Postharvest Tecnology of Horticultural Crops'. (Ed. AA Kader), 287-289.

LINS, HA; QUEIROGA, RCF; PEREIRA, AM; SILVA, GD; ALBUQUERQUE, JRT. 2013. Produtividade e qualidade de frutos de melancia em função de alterações na relação fonte-dreno. Revista Verde de Agroecologia e Desenvolvimento Sustentável 8: 143 - 149.

LONG, RL; WALSH, KB; ROGERS, G; MIDMORE, DJ. 2004. Source-sink manipulation to increase melon (Cucumis melo L.) fruit biomass and soluble sugar content. Australian Journal of Agricultural Research 55: 1241-1251.

MEDEIROS, JF; SANTOS, SCL; CÂMARA, MJT; NEGREIROS, MZ. 2007. Produção de melão Cantaloupe influenciado por coberturas do solo, agrotêxtil e lâminas de irrigação. Horticultura Brasileira 25: 538-543.

MELO, DM; RENATACASTOLDI, R; CHARLO, HCO; FRANCINE DE SOUZA GALATTI, FS; BRAZ, LT. 2012. Produção e qualidade de melão rendilhado sob diferentes substratos em cultivo protegido. Revista Caatinga 25: 58-66.

MELO, D.M. CHARLO, H.C.O.; CASTODI, R.; BRAZ, L.T. 2014. Dinâmica do crescimento do meloeiro rendilhado 'Fantasy' cultivado em substrato sob ambiente protegido. Biotemas 27: 19-29.

NOGUEIRA, ICC; PEDROSA, JF; SANTOS JÚNIOR, JJ; VALE, MFS; ANDRADE, FV. 2001. Qualidade de híbridos de melão submetidos à poda e diferentes densidades de plantio. Horticultura Brasileira 19: 254-257.

PURQUERIO, LFV; CECÍlIO FILHO, AB. 2005. Concentração de nitrogênio na solução nutritiva e número de frutos sobre a qualidade de frutos de melão. Horticultura Brasileira 23: 831-836.

QUEIROGA, RCF; PUIATTI, M; FONTES, PCR; CECON, PR. 2009. Características de frutos do meloeiro variando número e posição de frutos na planta. Horticultura Brasileira 27: 23-29.

SANTOS, FGB; NEGREIROS, MZ; MEDEIROS, JF; LOPES, WAR; SOARES, AM; NUNES, GHS.; FREITAS, FCL. 2014. Growth and yield of Cantaloupe melon 'Acclaim' in 
protected cultivation using agrotextile. Horticultura Brasileira 32: 55-62.

SANTOS, FGB; NEGREIROS, MZ; MEDEIROS, JF;NUNES, GHS; MEDEIROS, DC; GRANJEIRO, LC. 2015. Produção e qualidade de melão Cantaloupe em cultivo protegido temporariamente com agrotêxtil em Mossoró, Rio Grande do Norte. Revista
Ceres 62: 93-100.

SILVA, MC; SILVA, TJA; BOMFIM-SILVA, EM; FARIAS, LN; SIMMONDS, NW. Características produtivas e qualitativas de melão rendilhado adubado com nitrogênio e potássio. 2014. Revista Brasileira de Engenharia Agrícola e Ambiental 18: 581587.
VALANTIN-MORISON, M; VAISSIERE, BE; GARY, C; ROBIN, P. 2006. Source-sink balance affects reproductive development and fruit quality in cantaloupe melon (Cucumis melo L.). Journal of Horticultural Science and Biotechnology 86: 105-117. 